\title{
集団凝集性と集団志向の関係，および集団凝集性の 試合成績への効果
}

\author{
阿江美 恵子（淑徳保育生活文化専門学校） \\ （昭和59年 5 月 29 日 受付）
}

\begin{abstract}
The relationship between group cohesiveness and grouporientation, and the effect of group cohesiveness on volleyball team performance
\end{abstract}

\section{Mieko $\mathrm{Ae}^{1}$}

\begin{abstract}
The results of the previously reported studies on group cohesiveness/performance relationships in sport groups do not necessarily agree each other. Two reasons, if not any more, may be pointed out for such descrepancies, i.e., validity of measurement and suitability of the groups that are being investigated. The current study intended to clarify the latter of such two issues and thus investigated if group cohesiveness varied with group-orientation and high group cohesion resulted in successful team performances.

Three hundred and five female volleyballers of ages between 18 and 35 years volunteered as subjects to whom a questionnaire survey was conducted. They consisted of five housewives' teams $(\mathrm{N}=51)$, eight community club teams $(\mathrm{N}=71)$, five varsity teams $(\mathrm{N}=66)$ and twelve industrial workers' teams $(\mathrm{N}=117)$. Nature of the group was then studied and thus housewives' and community club teams were found to be recreation oriented while varsity and industrial workers' teams, competition oriented.

Group cohesiveness was measured by use of two scales, i.e., social affect scale and cohesiveness measures (directly assessed). The cohesiveness measures consisted of two subscales, namely interpersonal attraction-cohesion and belonging and task-cohesion. Such measurement was administered to each team.

The results may be summarised as follows:

1) Receration oriented teams had higher interpersonal attraction-cohesion and social affect score and lower belonging and task-cohesion than competition oriented teasm.

2) Significant effect of cohesiveness on team success was found only in belonging and taskcohesion items. The higher belonging and task-cohesion indices, the more the team seemed to be
\end{abstract}


successful in the competition.

From these results it was considered that it is necessary to control the level of group orientation to examine further the cohesiveness/performance relationship. And it was also suggested that cohesiveness in the view-point of task-cohesion would be a matter of interest in the future studies.

(Mieko Ae, "The relationship between group cohesiveness and group-orientation, and the effect of group cohesiveness on volleyball team performance", Jap. J. Phys. Educ., 29-4:315-23, March, 1985)

\section{栯}

スポーツ集団における集団凝集性一パフーマ ンス関係は,多くの研究者の肉心を集めているが， それらの研究結果は必ずしも一致していない. 両 者の正の関係は，以下の研究で報告されている. Martens and Peterson ${ }^{25)}$ は，彼らの開発した「ス ポーツ凝集性質問紙（sport cohesiveness questionnaire)」をバスケットボールチームに用い, 2 項目（集団所属意識之成員性の価値）之勝率の間 に正の関係を見出した。同様に，Peterson and Martens ${ }^{33)}$ 女試合成功がチーム内の凝集を高める ことを示している。同一尺度を用いて，Larders and Crum ${ }^{20)}$ (野球チームで, Bird ${ }^{3), 4)}$, Ruder and Gill'14パレーボールチームで, Carron and Ball ${ }^{7}$, Ball and Carron'住アイスホッヶーチーム で, Gruber ${ }^{15)}$, Landers, et al. ${ }^{22)}$, Widmeyer and Martens ${ }^{38)}$ はバスケットボールチームで，それぞ れ凝集性と試合成績との間に正の関係を見出して いる、また，Eitzen"11)はクリーク(小集団分裂)の 存在が勝率を減ずることを示した。ソシオメト

リックテストを用いた研究です，強いチームほど 相互選択が多く，凝集が高いことが見出されてい $3^{18), 23), 371}$.さらに，対人志向から集団凝集性を探 究した金子ら ${ }^{17)}$ は，Schutz ${ }^{36)}$ の FIRO-B 質問紙を 用いて，創造的で自由的活動の高い集団ほど凝集 性が大きいことを見出した。その他の尺度を用い たものです両者の正の関係が論じられてい $ろ^{30), 31)}$.

ところが，上述の結果とは逆の負の結果す見出 されている、Fiedler ${ }^{13)}$ は対人認知の類似度を凝集 性としてとらえ, 成員を互いに類似していないと 評価したチーム（つまり凝集性が低い）のはらが
類似していると評価したチームよりも試合成績が 良いことを見出した。 また，対人関係の好意度で 集団の凝集を測定した McGrath ${ }^{26)}$ はライフル チームで，好意的でないチームのほうが成績が高 いことを見出し， Landers and Lüschen ${ }^{211}$ は，ボー リングチームでは試合成㺓のよくないことがチー ムの凝集性の向上に効果があると主張した。さら に,ソシオメトリックテストを用いたレンク ${ }^{24)}$ は， 内部葛藤の大きなボートチームが，オリンピック で優勝したことを報告している。このような負の 関係は，共働作業 (co-acting) 課題であるライフ ルホホーリングホボートチームで主に見出されて おり, Carron and Chelladurai ${ }^{\mathbf{B}}$ は, 相互作用 (interacting)課題でのみ，凝集性とパフォーマン スの正の関係が主張できると述べている.

両者は無関係であるといら結果も得られてい $ろ^{26), 29)}$.

このよらな研究結果の矛盾の原因を探るため, Widmeyer and Martens ${ }^{38}$ は, どのような条件で 凝集性がパフォーマンスを予測するのかを決定し ようと試みた。その結果，凝集性は，(1直接評価 で評定されるとき，(2)チームの能力水準が統制さ れているとき，(3)課題が相互作用課題であるとき， パフォーマンスを予測すると結論した。また， Carron $^{61}$ は，凝集性自体の定義の問題と，他の媒介 変数の関与, 凝集性とパフォーマンスの因果関係 のあいまいさ，を問題点としてあげている。さら に, Chelladurai ${ }^{101}$ は，相互作用課題での凝集性の 重要さを論し，Gruber ${ }^{15)}$ は，競技水準の違いが 様々な凝集を生むことを指摘している，凝集性の 測定といら視点からみると，すべての凝集性の項 目が正の関係を支持しているのではないことも明 らかである ${ }^{20,25)}$. 従って, 結果の矛盾は, 凝集性が 
何を測定しているのかといらことと，どのような 集団を対象とするかによって生じていると言えよ 5.

後者のどのよらな集団を対象とするかといら観 点に立つと, 従来の研究では, 一時的に形成され た実験集団のよ5な小人数のチームが対象とされ ることが多かったが25),26),27),299,33),38)，学校代表のよ らな永続的なチームの研究るみられる2,33,4),77,31). 集団の比較では, Widmeyer and Martens ${ }^{38)}$ の主 張するような能力水準の違い, Gruber ${ }^{15)}$ の競技水 準の違い(子供と大学生の比較),さらに集団課題 の違い ${ }^{29)}$ (相互作用課題と共牦作業課題)が要因と してあげられている。しかし，集団の志向の違い による凝集性の比較はまだ行われていない。

本研究は，凝集性一パフォーマンス関係と，集 団の志向一凝集性関係を明らかにすることを目的 とする，集団の志向は，競技ーレクリェーション の両極でとらえ，それぞれの志向を持つ集団の凝 集性の比較を試み，凝集性研究をさらに前進させ るための基礎的資料を得ようとするすのである.

\section{方法}

\section{1. 策団㙂集性の湘定}

集団凝集性は，Festinger, et al. ${ }^{22)}$ の概念定義に 基つき，集団に対して抱く鬿力を測定する社会感 情測度 ${ }^{14)}$ と凝集性を直接評価させる凝集性測度の 2つから粠成した。

社会感情測度は 6 個の形容詞対からなる SD 尺 度である (Table 1).Griffitt and Veitch ${ }^{14)}$ は，環 境が不快な状況であれば, 社会的鬽力行動が減じ， 対人反応が負になることを見出している．この考 えに基ついて，チーム内が快適な状況であれば， 成員の社会的趎力行動は正に影㣪され，集団に対 して抱く魅力が增すと仮定した。

Table 1. Social affect scale.

\begin{tabular}{|c|c|c|}
\hline 心地よい & $1+1+1+1$ & 心地わるい \\
\hline 重い & $1+1+1+1+1$ & 良い \\
\hline 高い & $\vdash$ & 低い \\
\hline 悲しい & -1 & 幸福な \\
\hline 快 & +1 & 不快 \\
\hline 肯定的な & $1+1+1+1+1$ & 否定的な \\
\hline
\end{tabular}

Table 2. Cohesiveness measures.

1.あなたは、どれくらいクラブが好きですか。

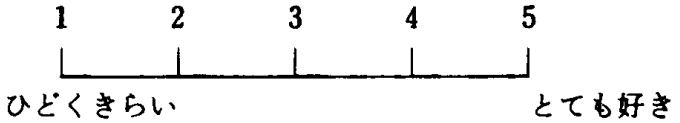

2. あなたは, クラブ以外の活動をする時, どれくらいク ラプの仲間と一腥に活功したいと思いますか。

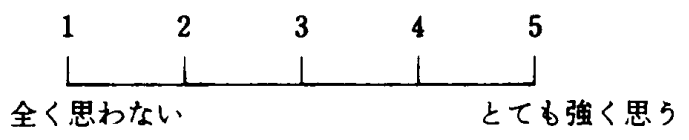

3.あなたは，クラブに所蝈しているという意識をどれ程 強く持っていますか。

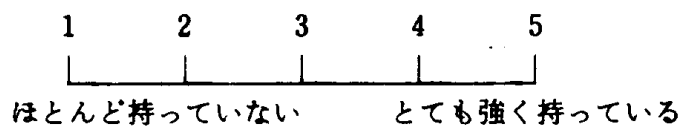

4.あなたは,クラプに所属していることにどれ程大きな 価値があると思いますか。

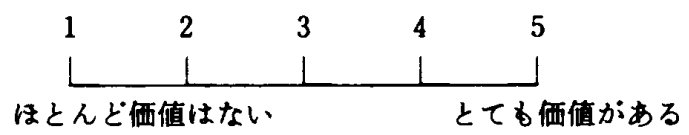

5.あなたは，あなたの所局していろクラブが，どれ程ま とまっていると思いますか。

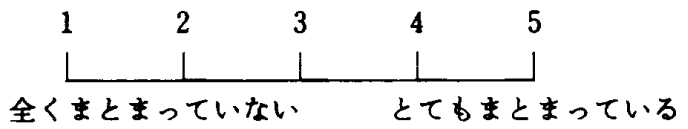

6. あなたのクラブの仲間は，全体的にどれくらい仲が いですか。

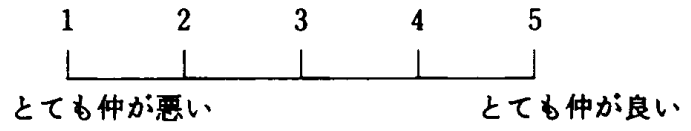

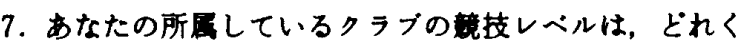
らいだと思っていますか。

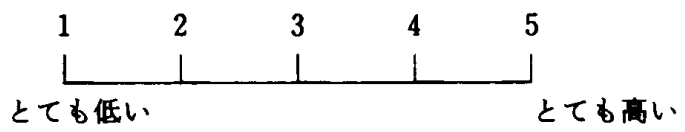

8. あなたにとって，クラブが武合でよい成交をおさめる ことは，とれれ程重要ですか。

$\begin{array}{lllll} & 2 & 3 & 4 & 5 \\ & 1 & 1 & & \\ \text { はとんど重要でない } & & & \text { とてる重要である }\end{array}$

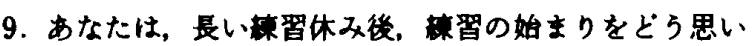
ますか。

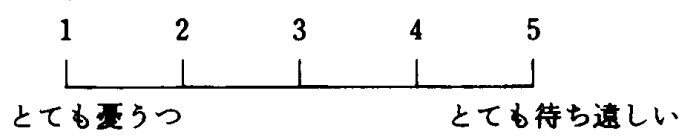

10. あなたは，クラブのふん囲気や人間俰がいやで, や めたいと思らことがありますか。

$\begin{array}{ccccc}1 & 2 & 3 & 4 & 5 \\ \text { L } & \text { L } & 1 & 1 & \\ \text { 全くそ5思わない } & & & \text { いつるそ5思5 }\end{array}$


凝集性測度は，Widmeyer and Mertens ${ }^{38)}$ の知 見に基づき，ソシオメトリック尺度を含まない凝 集の直接評価尺度を，文献の中から収集した。そ して短時間で記入できる項目数といらことから10 項目を選定した。 内訳は, Schachter, et al. ${ }^{35)}$ の 2 項目（集団の好嫌之他成員についての好嫌の評 定), Martens and Peterson ${ }^{25}$ の 4 項目（所属意 識, 価值観, チームワーク, 結合度の評定), Nixon ${ }^{31}$ )の 2 項目（競技レベル，成績についての評 定), 丹羽 ${ }^{30}$ の 2 項目（練習の雾囲気，練習の始玉 りについての好意度の評定) である（Table 2)。 各項目は，5段階評定尺度上に回答させた。

\section{2. 的重対象}

種目は相互作用課題であるバレーボールであ る. 対象は女子に限定し，ママさんバレーボール チーム(荻城県新治郡大会出場)，5千ー51名，昭 和53年度全日本女子 9 人制バレーボール大会出場 チームのらち, 学生 5 チーム 66 名, 同好クラブ 8 チーム71名, 実業団 12 チーム117名, 合計 30 チーム, 305名であった。年龄は18歳から35歳にわたった。

\section{3. 雕查手繶}

調查期間は，昭和53年11月中旬一下旬。ママさ んバレーボールチームについては，郡大会会場で 調査用紙を配布し，その場で記入させ回収した。 9 人制大会出場チームについては，大会前日の監 督会議で配布し，当日のうちに記入するようにマ ネーシャーに依頼し，回収は翌日試合会場で行っ た。調査は試合成績が判明する以前に完了したの で，試合結果の影箁は受けなかったものと考えら れる。

\section{結果および考菉}

本研究の計算は, 筑波大学大型計算機で, SPSS 統計プログラムパッケージを用いて行った。

\section{1. 測定の梌尌}

社会感情測度は, Griffitt and Veitch ${ }^{14)}$ に従い, 6 項目の合計点 (項目 $1,3,5,6$ は逆転項目)を 個人の得点として用いた。

凝集性測定の10項目については各項目と合計点 の相関をとり項目分析を行った（Table 3). その 結果, 最も相関の低かった項目 7 （競技レベルの
Table 3 Correlation between a cohesiveness measure and a sum of measure.

\begin{tabular}{llllllllllll}
\hline $\begin{array}{l}\text { Item } \\
\begin{array}{l}\text { Corre. } \\
\text { lation }\end{array}\end{array}$ & 1 & 2 & 3 & 4 & 5 & 6 & 7 & 8 & 9 & 10 \\
\hline $\mathrm{R}$ & 0.72 & 0.52 & 0.64 & 0.64 & 0.67 & 0.62 & 0.36 & 0.43 & 0.57 & 0.54 \\
\hline
\end{tabular}

Table 4 Varimax rotated factor matrix. (Cohesiveness measures)

\begin{tabular}{|c|c|c|c|}
\hline & & \multicolumn{2}{|c|}{ Factor loading } \\
\hline & & Fac. 1 & Fac. 2 \\
\hline \multirow[t]{9}{*}{ Item } & 1 & 0.649 & 0.327 \\
\hline & 2 & 0.267 & 0.423 \\
\hline & 3 & 0.159 & 0.758 \\
\hline & 4 & 0.344 & 0.459 \\
\hline & 5 & 0.713 & 0.296 \\
\hline & 6 & 0.553 & 0.287 \\
\hline & 8 & 0.057 & 0.534 \\
\hline & 9 & 0.584 & 0.118 \\
\hline & 10 & 0.519 & 0.033 \\
\hline \multicolumn{2}{|c|}{ value } & 3.848 & 1.281 \\
\hline \multicolumn{2}{|c|}{$\begin{array}{l}\text { Variance } \\
\text { percent }\end{array}$} & 38.7 & 14.2 \\
\hline
\end{tabular}

評価）を内容吟味の結果，不適切項目として削除 した。残り 9 項目に主因子分析を行い，凝集性測 定内に潜む因子を検討した。 その結果, 固有値 1.00 以上で 2 因子が抽出された。 2 因子各々に対する 各項目の因子負荷吾は，Table 4に示した。

第 1 因子に高い因子負荷量を示したのは，項目 $1,5,6,9,10 て ゙$ ，内容から「対人魀力に上る凝 集」因子と名付けた，第 2 因子に高い因子負荷量 を示したのは, 項目 $2,3,4,8$ で，「所属・課題 による凝集」因子と名付けた。

因子分析の結果，凝集性測度には 2 次元の意味 が含まれることが明らかとなった。凝集性を多次 元でとらえる視点は，他の研究者によっても主張 されている5),16),28),32). しかし，統一見解は合意され ておらず, 本研究で得られた 2 次元は, Carron ${ }^{5 / の}$ 社会的凝集と課題凝集の区分に近いと考えられ る.

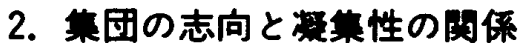

対象チームを全国大会での優勝をめざすか否か を基準として，競技ーレクリェーション志向に分 
Score

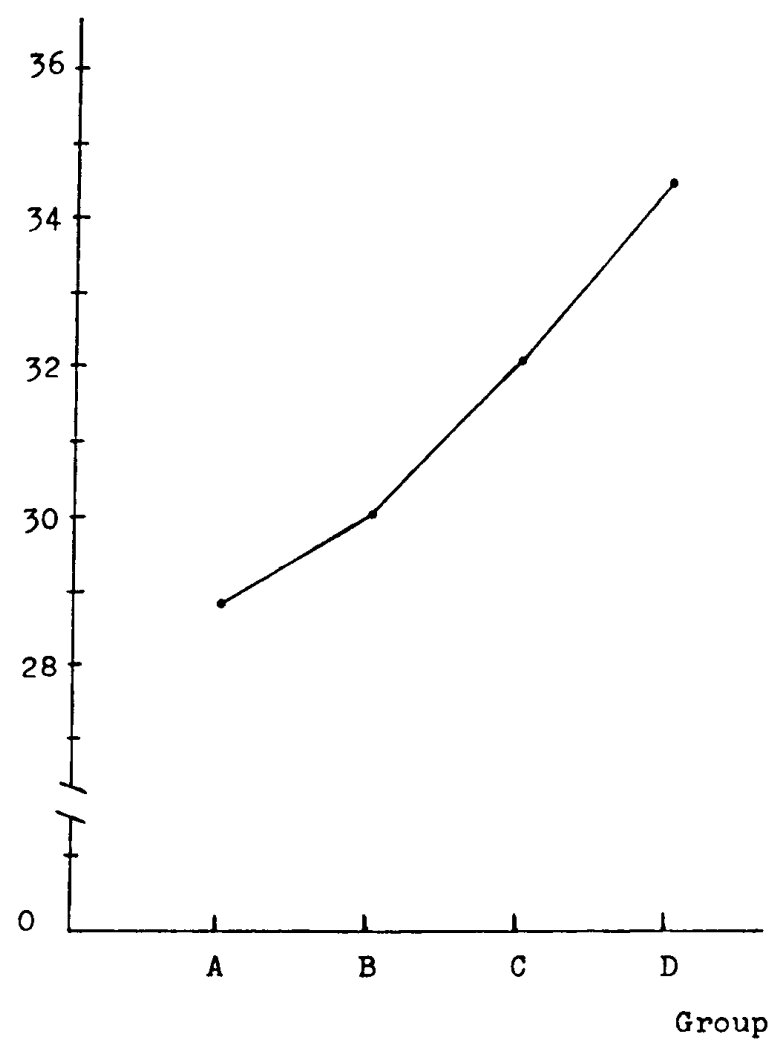

Fig. 1 Social affect score.

類を行らと，実業団（A群），学生（B群）は競技 志向, 同好クラブ(C群), ママさんバレーボール チーム（D群）はレクリエーション志向と考克る ことができる。

各群ごとの社会感情得点の平均を示したものが Fig. 1である. 集団間の差を明らかにするために, 一要因分散分析を行った結果，統計的な有意差が 認められた $(p<0.01$, Table 5).ささらに多重比較 を行らと，A群とB群間以外のすべての群間に有 意差が認められた $(\mathrm{p}<0.05$, Table 6). 集団に対 する社会的感情は，D， C, B, A の順に低下してお ク,このことは, レクリェーション志向の大きい

Table 5 Summary resulted from oneway analysis of variance. (Group-ori. X Social affect scale)

\begin{tabular}{crrrc}
\hline S & SS & DF & \multicolumn{1}{c}{ MS } & F \\
\hline Between groups & 1228.61 & 3 & 409.53 & $37.42^{* *}$ \\
Within groups & 3294.58 & 301 & 10.95 & \\
\hline Total & 4523.19 & 304 & & \\
\hline$* *: p<0.01$ & & & &
\end{tabular}

Table 6 Multiple comparison. (Social affect scale)

\begin{tabular}{|c|c|c|c|}
\hline$A$ & B & $\mathrm{C}$ & $\mathrm{D}$ \\
\hline A & N.S. & $*$ & * \\
\hline B & & * & * \\
\hline $\mathrm{C}$ & & 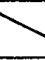 & * \\
\hline $\mathrm{D}$ & & & \\
\hline
\end{tabular}

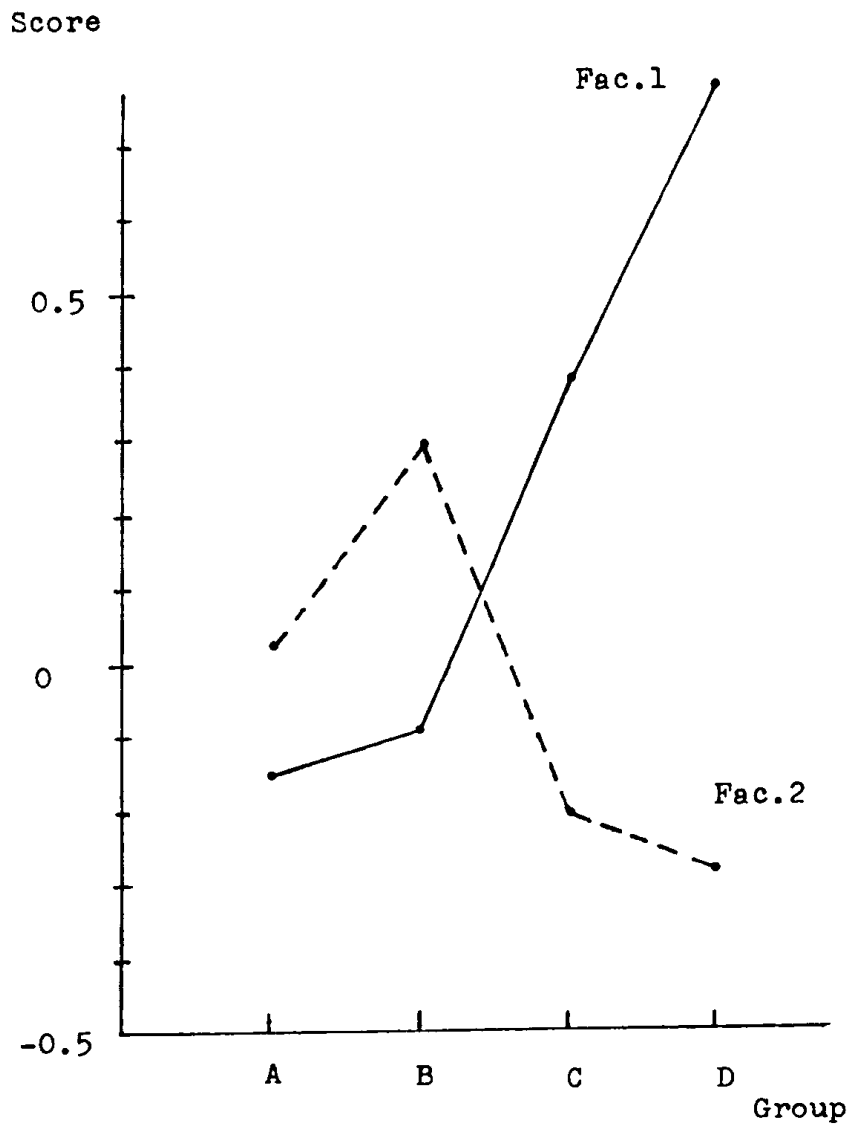

Fig. 2 Cohesiveness factor score. Fac. 1 : interpersonal attraction-cohesion Fac. 2 : belonging and task-cohesion

Table 7 Summary resulted from oneway analysis of varience. (Group-ori. X Interpersonal attraction-cohesion)

\begin{tabular}{crrrr}
\hline S & SS & DF & \multicolumn{1}{c}{ MS } & F \\
\hline Between groups & 38.29 & 3 & 12.76 & $49.08^{* *}$ \\
Within groups & 78.05 & 301 & 0.26 & \\
\hline Total & 116.34 & 304 & & \\
\hline$\cdots: p<0.01$ & & & &
\end{tabular}


Table 8 Multiple comparison. (Interpersonal attraction-cohesion)

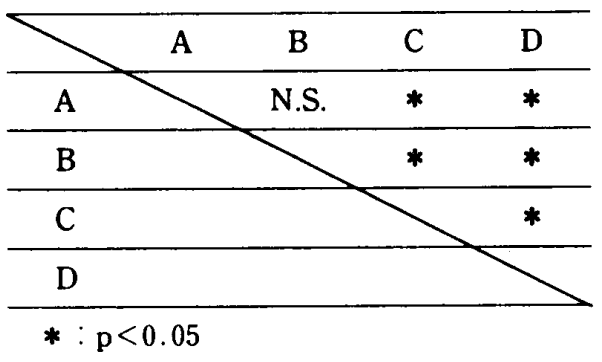

ほらが，集団に対する鬽力が大きいことを示する のである.

次に凝集性測度と各群の関俰をみるために各群 ごとの因子得点を 2 因子各々で算出した。（Fig. 2).「対人魅力による凝集」(Fac. 1) では，D，C, $\mathrm{B}, \mathrm{A}$ の順に得点が低くなり，一要因分散分析の結 果で統計的な有意差が認められた $(\mathrm{p}<0.01$ ， Table 7).さらに多重比較を行らと，A，B群間に 差は認められなかったが，その他の群間には $5 \%$ 水準で有意差が認められた（Table 8)。このこと から，「対人魅力による凝集」も，社会感情測度之 同様に, レクリェーション志向が大きいはど高く なると考えられる。

「所属・課題による凝集」(Fac. 2) では，社会 感情測度，「対人鬿力による凝集」とは異なり， $\mathrm{B}$, $\mathrm{A}, \mathrm{C}, \mathrm{D}$ 群の順に得点が低くなった。分散が同質 でなかったので，ウェルチの方法を用いて群間の 差を検定した結果，統計的な有意差が認められ $(\mathrm{F}=36.98, \mathrm{df}=3.12, \mathrm{p}<0.01)$, 多重比較でも， C, D 群間に有意差が認められなかった以外は，各 群間に有意差が見出された（Table 9）。

集団志向からこれらの結果をみると，競技志向

Table 9 Multiple comparison. (Belonging and task-cohesion)

\begin{tabular}{|c|c|c|c|}
\hline$A$ & B & $\mathrm{C}$ & D \\
\hline $\mathrm{A}$ & * & * & * \\
\hline B & & * & * \\
\hline $\mathrm{C}$ & & & N.S. \\
\hline $\mathrm{D}$ & & & \\
\hline
\end{tabular}

Table 10 Intercorrelation among three dependent scales.

\begin{tabular}{lccc}
\hline & Fac. 1 & Fac. 2 & $\begin{array}{c}\text { Social affect } \\
\text { scale }\end{array}$ \\
\hline Fac. 1 & 1.000 & 0.323 & 0.641 \\
\hline Fac. 2 & 1.000 & 0.305 \\
\hline $\begin{array}{l}\text { Social } \\
\text { affect }\end{array}$ & & 1.000 \\
\hline
\end{tabular}

の A, B 群の得点が高く, レクリェーション志向 の C, D 群の得点が低いことがわかる. 従って, 競 技志向が大きいはらが，所属・課題による凝集が 大きくなるといらことができる。

得られた 3 尺度間の関連をみるために，相互の 相関係数を算出した(Table 10)。なお，凝集の 2 因子は因子負荷量の大きな項目の合計点を計算し て用いた。「対人魅力による凝集」と「社会感情測 度」は0.641の相関係数を示し，この 2 尺度の各群 の得点傾向を考え合わせると，両者は，凝集性の 対人魅力側面を測定していると考えることができ る。

まとめると,レクリェーション志向では, 社会 的感情が好意的で，対人鬿力による凝集が大きい が，競技志向に比べると，所属・課題による凝集 が小さい，逆に，競技志向では所属・課題による 凝集が大きく，対人魅力は低かった。これは，競 技志向の集団が，集団内の対人関係より 課題の側面を重視していることを示すものである と考えられる。

従来，集団凝集性については，対人鬽力側面の みが強調されてきたが，競技志向の強いスポーツ 集団の研究には, 本研究で示された課題を重視す る凝集性の側面も考えねばならないことが主張で きるであろう，凝集性一パフォーマンス関係につ いての研究結果の不一致は, この視点の欠除が一 因ではないかとも推測できる。

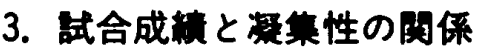

9 人制大会出場チームのみを分析に用いた。 大 会の成績から，ベスト16に残った 6 チームを成功 群 ( $\mathrm{H}$ 群)，1 回戦敗退の 5 チームを不成功群 ( $\mathrm{L}$ 群）とした，H群を構成したのは，学生 2 チーム と実業団 4 チームであり，L群は学生 1 チームと 
Table 11 Means and standard deviations for winners and losers for three dependent scales.

\begin{tabular}{ccccc}
\hline Scale & & Social affect & Fac. 1 & Fac. 2 \\
\hline Group H & $\mathrm{M}$ & 28.97 & 0.100 & 0.296 \\
& $\mathrm{SD}$ & 4.93 & .676 & 0.342 \\
& $\mathrm{~N}$ & 69 & 69 & 69 \\
\hline Group L & $\mathrm{M}$ & 29.78 & 0.100 & -0.382 \\
& $\mathrm{SD}$ & 1.55 & 0.357 & 0.460 \\
& $\mathrm{~N}$ & 48 & 48 & 48 \\
\hline $\mathrm{t}$ & & 1.27 & 0.00 & $9.06^{* *}$ \\
\hline$* * \mathrm{p}<0.01$ & & &
\end{tabular}

同好クラプ 4 チームであった。

2 群の社会感情測度, 凝集性測度（2 因子の因 子得点）の得点を比較したところ,「所属・課題に よる凝集」のみで有意差が認められた（Table 11). 従って, 対人鬿力による凝集は試合成樍の違 いによって差はなかったが，所属・課題による凝 集が大きいほど、試合成績が良いことが示された。

この結果に，集団の志向が全く関与していない とは言いきれない。しかし，有意差の認められた のが，「所属・課題による凝集」のみで，志向の違 いで得られた凝集性の得点傾向とは同じではな かった。従って，ここで得られた結果は，試合成 績の違いに影響を与える要因と考えることができ る.

成功群で「所属・課題による凝集」が大きかっ たことは，凝集性の課題側面とパフォーマンスの 正の関係を支持するものである.このことから， チーム内の課題凝集を高めることが，試合成績の 向上に貢献すると考えることができる。

対象としたチームは，全国大会出場までの過程 で，チーム内の人間環境が良好になり，対人魅力 が一様に高くなっていると考えることができる。 そのため，凝集の対人鬿力側面が全く試合成績に 影響を与えないと言いきることは早すぎる，凝集 性の 2 つの側面とパフォーマンスの明らかな関係 は，さらに志向を限定した研究の結果を待たなけ ればならないであろう。

本研究では，集団凝集性に 2 次元の側面がある ことが明らかにされたが，測定尺度は，さらに問 題にすべきである.この知見の一般化のためには，
今回の結果では項目数の少なかった課題側面の凝 集の尺度を改めて作成することが必要であろう。

また，凝集性と集団志向には関連がみられたの で，凝集性一パフォーマンス関係を論ずるために は，志向レベルを限定する必要があると考えられ る.

試合成績と凝集性の関係は一部が支持された。 本研究は，凝集性から試合成樍へとい5因果の方 向を論じたものであるが，両者の因果関係につい ては，どららが原因であるか，結果であるかとい う議論が続いている，凝集性を原因とする研究は 多いが7),191,26),277,29),31),33)，近年, 逆の方向を主張する 研究が相いついでいる11,7),201,34. これらのことを考 えると，凝集性が集団内でどのように変化するか に主眼を置いた，継続的な研究が必要となるであ ろ5.

\section{結铪}

本研究の結果, 以下の 3 点が明らかとなった。

(1) 集団凝集性は，「対人魅力」と「所属・課題」 側面の 2 次元から成った。

(2)集団志向と集団凝集性には関連がみられた。 すなわち，リクリェーション志向は対人鬿力凝集 が大きく，所属・課題凝集が小さく，競技志向は， その逆の凝集傾向を示した.

(3) 所属・課題凝集は, 試合成績と正の関係を示 したが，対人趎力凝集は，のちの試合成績に有意 な影㲫は与えなかった。

付記, 本研究は, 昭和 55 年度筑波大学大学院体育科 学研究科馀文を，加筆修正したものである。

上越教育大学教授松田岩男先生には，多大な御指導 をいただきした。ここに記して，謝意を表します。

\section{引用・参考文献}

1) Bakeman, R. and Helmreich, R., "Cohesiveness and performance : Covariation and causality in an undersea enviroment," Journal of Experimental Social Psychology, 11-5 : 478-89, 1975.

2) Ball, J.R. and Carron, A.V., "The influence of team cohesion and participation motivation upon performance success in intercollegiate ice hockey," Canadian Journal of Applied Sport Science, 1: 
271-75, 1976 .

3) Bird, A.M., "Development of a model for predicting team performance," Research Quarterly, 48-1:24 $-32,1977$.

4) Bird, A.M., "Team structure and success as related to cohesiveness and leadership," Journal of Social Psychology, 103-2:217-23, 1977.

5) Carron, A.V., Social psychology of sport, Mouvement Publications: New York, 1980.

6) Carron, A.V., "Cohesiveness in sport groups : Inter. pretations and considerations," Journal of Sport Psychology, 4 : 123-38, 1982.

7) Carron, A.V. and Ball, J.R., "An analysis of causeeffect characteristics of cohesiveness and participa. tion motivation in intercollegiate hockey," International Review of Sport Sociology, 12 : 49-60, 1977.

8) Carron, A.V. and Chelladurai, P., "Cohesiveness as a factor in sport performance," International Review of Sport Sociology, 16-2:21-43, 1981.

9) Carron, A.V. and Chelladurai, P., "The dynamics of group cohesion in sport," Journal of Sport Psy. chology, 3 : 123-39, 1981.

10) Chelladurai, P., "Group cohesiveness, leadership, and athletic performance," Canadian Association for Health, Physical Education, and Recreation Journal, 47-5:15-21, 1981.

11) Eitzen, D.S., "The effect of group structure on the success of athletic teams," International Review of Sport Sociology, 8:7-17, 1973.

12) Festinger, L., Schachter, S. and Back, K., Social pressures in informal groups. A study of human factors in housing, Stanford University Press: California, 1963 (Reissued). pp. 151-77.

13) Fielder, F.E., "Assumed similarity measures as predictors of team effectiveness," Journal of Abnormal and Social Psychology, 49-3 : 381-88, 1954.

14) Griffitt, W. and Veitch, R., "Hot and crowded: Influences of population density and temperature on interpersonal affective behavior," Journal of Personality and Social Psychology, 17-1 : 92-98, 1971.

15) Gruber, J.J., "Comparison of relationships among team cohesion scores and measures of team success in male varsity basketball teams," International Review of Sport Sociology, 16-4 : 43-56, 1981.

16) Hagstrom, W.O. and Selvin, H.C., "Two dimensions of cohesiveness in small groups," Sociometry, 28-2 : 30-43, 1965.

17）金子吉三市・丸山晋久・奥 保宏「体育学習の场にお

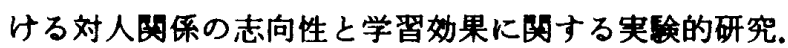
(その一)対人网係における志向性の分析. (その二)リー ダーの両立性とゲーム内容の分析」鹿児島大学体育科報 告, $7: 9-20,1971$.
18）川井 昂・永福正俊・山岸明郎・椛沢聖子「運動部集 団の濑集性に的する一考察」日本大学人文科学研究所研 究紀要, 3-17：197-205, 1975.

19) Klein, M. and Christiansen, G., "Group composition, group structure, and group effectiveness of basketball teams," In Loy, J.W. Jr. and Kenyon, G.S. (Eds.), Sport, culture, and society, McMillan : London, England, 1969. pp. 397-407.

20) Landers, D.M. and Crum, T.F. "The effect of team success and formal structure on inter-personal relations and cohesiveness of backetball team," International Journal of Sport Psychology, 2-2:88-96, 1971.

21) Landers, D.M. and Luschen, G., "Team performance outcome and the cohesiveness of competitive coacting groups," International Review of Sport Sociology, 9 $-2: 57-69,1974$.

22) Landers, D.M., Wilkinson, M.O., Hatfield, B.D. and Barber, H., "Causality and the cohesion-performance relationship," Journal of Sport Psychology, 4-2 : 170 $-83,1982$.

23) Lefebvre, L.M. and Cunningham, J.D., "The successful football team: Effects of coacting and team cohesiveness," International Journal of Sport Psychology, 8-1:29-41, 1977.

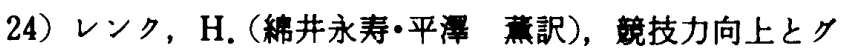
ループ・ダイナミックス,プレスギムナスチカ, 1977.

25) Martens, R. and Peterson, J.A., "Group cohesiveness as a determinant of success and member satisfaction in team performance," International Review of Sport Sociology, 6: 49-61, 1971.

26) McGrath, J., “The influence on positive interpersonal relations on adjustment and effectiveness in rifle teams," Journal of Abnormal and Socioal Psy. chology, 65-6:365-75, 1962.

27) Melnick, M.J. and Chemers, M.M., "Effects of group social structure on the success of basketball teams," Research Quarterly, 45-1:1-8, 1974.

28) Michalachki, A., Group cohesion reconsidered, University of Western Ontario, 1969 (from Widmeyer, W.N., When cohesiveness predicts performance outcome in sport, Unpublished doctoral dissertation, University of Illinois, 1977).

29) Myers, A., "Team competition, success, and the adjustment of group members," Journal of Abnormal and Social Psychology, 65-5:325-33, 1962.

30）丹羽劭昭，「集団妹力からみた運動部の凝集性」丹羽劭 昭ら(編)，体育集団の研究,タイムス, 1972. pp. 333-58.

31) Nixon, H.L. II., "Team orientations, interpersonal relations, and team success," Research Quarterly, 47 $-3: 429-35,1976$.

32) Nixon, H.L. II., "Reinforcement effects of sports 
team success cohesiveness-related factors," International Review of Sport Sociology, 12-4:17-38, 1977.

33) Peterson, J.A. and Martens, R., "Success and residential affiliation as determinants of team cohesiveness," Research Quarterly, 43-1:62-76, 1972.

34) Ruder, M.K. and Gill, L.D., "Immediate effects of win-loss on perceptions of cohesion in intramural and intercollegiate volleyball teams," Journal of Sport Psychology, 4-3 : 227-34, 1982.

35) Schachter, S., Ellertson, N., McBride, D. and Gregory, D., "An experimental study of cohesiveness and productivity," Human Relations, $4: 229-38,1951$. 36) Schutz, W.C., FIRO : A three-dimensional theory of interpersonal behavior, Rinehart: New York, 1958.

37) Vanfraechem-raway, R., "Edude de la pe rsonnalite sociale du sportif en fonction de la structuration de son equipe," International Journal of Sport Psychology, 7-3:169-86, 1976.

38) Widmeyer, W.N. and Martens, R., "When cohesion predicts performance outcome in sport," Research Quarterly, 49-3:372-80, 1978. 